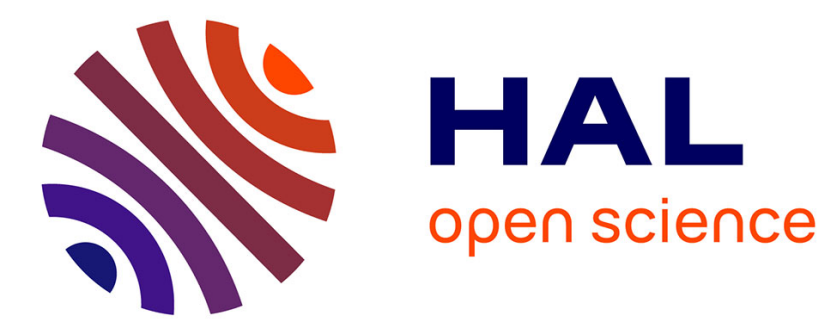

\title{
Regulating a particular form of migration at the European level: the Council of Europe and intercountry adoptions (1950-1967)
}

Yves Denéchère

\section{- To cite this version:}

Yves Denéchère. Regulating a particular form of migration at the European level: the Council of Europe and intercountry adoptions (1950-1967). Peoples and borders: movement of persons in Europe, to Europe, from Europe (1945-2015), Nov 2014, Padova, Italy. halshs-01101137

\section{HAL Id: halshs-01101137 \\ https://shs.hal.science/halshs-01101137}

Submitted on 7 Jan 2015

HAL is a multi-disciplinary open access archive for the deposit and dissemination of scientific research documents, whether they are published or not. The documents may come from teaching and research institutions in France or abroad, or from public or private research centers.
L'archive ouverte pluridisciplinaire HAL, est destinée au dépôt et à la diffusion de documents scientifiques de niveau recherche, publiés ou non, émanant des établissements d'enseignement et de recherche français ou étrangers, des laboratoires publics ou privés. 


\title{
Regulating a particular form of migration at the European level: the Council of Europe and intercountry adoptions (1950-1967)
}

\author{
Yves Denéchère*
}

\section{Introduction}

As during the Second World War, the postwar period favoured intra-European movements of displaced, refugee, lost, and surviving children. ${ }^{1}$ These transfers constituted de facto intra-European movements of people, of which international adoptions were the most successful legal manifestations. The history of these "intercountry adoptions", as they were called at the time, shows that in the 1940s and 1950s, movement within Europe was coupled with a movement from Europe toward the United States. Then from the 1960s onward, an intercontinental movement developed from Asia toward Europe, then another from Latin America toward Europe (very significant in the 1980s) and finally in the 1990s from Africa toward Europe, and new intra-European movements from the East toward the West. ${ }^{2}$ The three dimensions indicated in the title of the conference (in Europe, to Europe, from Europe) have thus been well presented in the study of international adoption. Although this is, above all, the creation of a legal parent-child relationship in order to give a family to a child who does not have one (and not the opposite), it could also be considered as a particular form of migration, whether seen as a modern version of traditional circulation of children - well studied by anthropologists - or as a solution to demographic, economic, and social problems. ${ }^{3}$ Impressive peaks of the number of international adoptions in the 1980s and 1990s strengthened the migratory approach. However their clear drop over the past several years has brought experts back to the question. ${ }^{4}$

Here, it is a question of returning to the origins of "intercountry adoptions" and studying how this nascent transnational social phenomenon was seen from the beginning as a particular type of migration which necessitated regulation at the international level. Europe found itself at the centre of the first movements - with the children's home countries and their host countries - how did the Council of Europe, institution created in 1949, take hold of this question and how did it contribute to regulating the phenomenon?

\footnotetext{
1 * Professor of Contemporary History, University of Angers - CNRS, UMR 6258 CERHIO

Kjersty Ericsson and Eva Simonsen (ed.), Children of World War II: The Hidden Enemy Legacy, Oxford/New York 2005. Tara Zahra, The Lost Children. Reconstructing Europe's Families after World War II, Harvard 2011.

Yves Denéchère, Des enfants venus de loin. Histoire de l'adoption internationale en France, Paris 2011.

3 Richard H. Weil, International adoptions: The quiet migration, International Migration Review, No. 18-2, (1984), p.276-293. Brigitte Trillat, Une migration singulière : l'adoption internationale, in L'adoption des enfants étrangers, CIE-UNICEF, Paris 1993, p.15-25.

4 Kirsten Lovelock, Intercountry adoption as a migration practice, International Migration Review, n³4, (2000), p.907-949. Peter Selman, Intercountry adoption in the new millennium: the "quiet migration" revisited, Population Research and Policy Review, No. 21, (2002), p.205-225.
} 
The sources mobilised firstly for this contribution were obviously the archives of the Council of Europe itself. Unfortunately, the Central Archives of the Council of Europe conserved in Strasbourg, in particular Thematic file 105 "Children", could not be consulted. Despite a request sent in due form in July 2014, then a letter addressed to the general secretary, they were inaccessible "because of a lack of personnel and relocation of a part of the archives..." and remain so now. ${ }^{5}$ Fortunately, documents produced by the Council of Europe (such as reports, projects, and various committee work) are available for consultation in the Archives of the French Foreign Affairs Ministry (in La Courneuve), particularly the collections "Administrative Conventions and Consular Affairs" and in the archives of the Ministry of Public Health and Population (National Archives).

\section{A - Migrations of Children in Postwar Europe}

\section{$\underline{\text { I - Lost children, sought-after children }}$}

In Europe, the demographic results of the Second World War were very different to those of the First because of the great number of civilian victims. Data specific to children are even heavier because they figured, like other categories of the population, among the victims or the survivors. Added to the orphans of soldiers killed in combat were orphans whose parents were victims of bombings or the concentration and extermination camps of Nazi Germany. There were also hundreds of thousands of children born from rapes or love affairs during invasions, occupations and detentions, left behind in the disorder at the end of the war, and whose fate illustrated the disarray of European societies. ${ }^{6}$ The question of the place reserved for children born to Allied soldiers arose very early in occupied Germany. ${ }^{7}$

In France, from its creation in April 1945, the High Consulting Committee on Population and the Family (Haut Comité consultatif de la Population et de la Famille, or HCPF) recommended turning the flows of refugees coming from Germany toward France. During a meeting on 18 May 1945, General de Gaulle asked the HCPF to examine bringing children of all nationalities to France, who were "currently orphaned or isolated in Germany." Immigration proved essential to guarantee

5 Consultation request dated 10 July 2014 and letter to Bjorn Berge, Director of the Cabinet of the COE Secretary General, 11 July; response from Ute Dahremöller, Director General of Administration of the Council of Europe, 25 August 2014.

6 Tara Zahra, note 1, introduction : "Civilization in disarray", p.1-23.

7 Heide Fehrenbach, Race after Hitler. Black Occupation Children in Postwar Germany, Princeton 2007, Chapter 5: "Whose children, theirs or ours? Intercountry adoptions and debates about belonging ". 
France's recovery. It meant welcoming children who bore promises for the future and to make French citizens out of them to replace those who were lacking due to a low birth rate. For Pierre Pflimlin, Undersecretary of State to the Population, it meant carrying out a veritable "blood transfusion." ${ }^{8}$ In April 1946, he specified "that it was no longer only a question of children with French blood in their veins." And adoption could help this regeneration. In nationality law (Ordinance of 19 October 1945), Article 35 stipulated: "The child who was subject to adoptive legitimization (adoption while breaking links with the biological family) acquires French nationality if his adoptive father is French." For simple adoption - (maintaining links with the biological family), Article 55 applied: "The child adopted by a person with French nationality can, until he reaches legal age, declare [...] that he claims French nationality." ${ }^{9}$

These reflections wholly illustrate the population policy common in postwar France. The country had to keep all its children, including those born to French mothers and occupying German soldiers or American GIs come to liberate the country: after the war, specialised nurseries took responsibility for Franco-American babies. The number of children born to French mothers and German soldiers under the Occupation from 1940 to 1944 are estimated to have been in the tens of thousands. ${ }^{10}$ Those abandoned by their mothers were adopted by French families, particularly thanks to the association La Famille Adoptive Française. It was also called upon to organise the adoption of children coming from Germany after 1945. Born to German mothers and occupying French soldiers, ${ }^{11}$ often not recognized by their fathers and abandoned by their mothers under social pressure, several hundred were adopted in France between 1946 and 1950, consituting one of the first large movements of intra-European international adoption. ${ }^{12}$

French authorities estimated it necessary to retrieve French children born in Germany and decided, depending on the case, either to bring them back to France to live with their paternal family, or to entrust them to Child Aid Services for placement or adoption. General Koenig, Commander-in-chief of French forces in the French Zone of Occupation Zone (FZO), gave orders to take a census of the children born to French or Allied soldier fathers. The Service of Displaced Persons and Refugees (DPR) was responsible for verifying if the father had acknowledged paternity and if the mother intended to raise or abandon her child. The first question raised was the

Tara Zahra, note 1, p.146.

9 Paul-André Rosental, L'intelligence démographique. Sciences et politiques des populations en France (1930-1960), Paris 2003, p.110-113.

10 Fabrice Virgili, Naître ennemi, Paris 2009.

11 Rainer Hudemann, Secret loves: French Soldiers and German Women, in It Started with a Kiss. German-Allied Relations after 1945, Allied Museum, Berlin 2005, p.28-37.

12 Yves Denéchère, Des adoptions d'Etat : les enfants de l'occupation française en Germany, Revue d'Histoire Moderne et Contemporaine, $\mathrm{n}^{\circ}$ 57-2, (2010), p.159-179 
acknowledgement of paternity by occupying soldiers. Cases varied greatly: known or unknown pregnancy, rape, departure of the father with no forwarding address, refusal to acknowledge, acknowledgement but no taking of responsibility. Thus, a non-commissioned officer wrote about the mother of his child: "I acknowledge that she is pregnant as a result of our relations. I consider however this girl as a friend and I honourably request that the child be delivered to the French government." ${ }^{13}$ In this way, hundreds of children born in Germany were adopted in France by French families who most often hid the child's origins and even the adoption itself. It must be stated that these movements of children were organised in secret and in the context of completely unstable Franco-German relations. ${ }^{14}$

\section{$\underline{\text { II -The beginnings of "intercountry adoptions" }}$}

After the Second World War, aid to children was reorganised internationally. UNICEF, created in 1946, aimed first and foremost to support children facing the misery of the end of the war; it did not and would never see to adoption. The International Union for Child Welfare (IUCW) was very wary of international adoptions. Its publication International Child Welfare Review regularly and heatedly mentioned a practice which it did not consider necessary to come to the aid of children in need. ${ }^{15}$ International Social Service (ISS) was the international organisation most involved in the reflection on international adoption as a response to the existence of children without parents, while making sure of a certain number of guarantees. ${ }^{16}$

Faced with the great distress of numerous children, a surge of international generosity manifested itself to adopt children who had little to no chance of being adopted in their own countries. The Swedish were particularly attentive to this question. Finnish children were adopted in Sweden, then in the 1950s, Swedes working in other European countries adopted children on site from Greece, Yugoslavia, or elsewhere. Of these children, 240 were brought back to Sweden between 1950 and the mid-1960s. ${ }^{17}$ Since that time, the country has had one of the highest rates of international adoption. The same phenomenon existed among French expatriates: in 1952, authorities pondered ways to validate acts of adoption of foreign children when the adoptive French

13 Foreign Affairs Ministry - France (from now on FAM), Archives of the French Occupation of Germany, Collections of Displaced Persons and Refugees, DPR 285, "Recensement des enfants dont l'un des parents est ressortissant des nations unies", s.d. ; DPR 396, letter from a non-commissioned officer, 31 August 1946.

14 To know more: Yves Denéchère, note 12.

15 Christopher Bagley (ed.), International and Transracial Adoptions, Newcastle 1993, p.160-163.

16 Jean-Claude Nicolle, Le service social d'aide aux émigrants et l'adoption, in L'adoption internationale, colloque Louis Chatin, 1994, ronéotypé, p.41-44.

17 Françoise Maury, L'adoption interraciale, Paris 1999, p.26. 
families lived abroad. ${ }^{18}$ In certain European regions (like in Italy and Greece) the overall economic situation and the absence of fathers killed in the war also gave rise to hordes of children taken in by institutions who were available for adoption at home or in neighbouring countries. In 1954, the artist Josephine Baker, after having adopted two children from Japan, brought little Jari home from one of her tours in Finland and then continued building her "Rainbow tribe". Given great media coverage in France, Belgium and Switzerland particularly, it is very difficult for the historian to evaluate the impact this single experiment had on the development of intercountry adoption. ${ }^{19}$

But international adoptions in the 1950s were especially done from European countries toward the United States. In bringing European children across the Atlantic, Americans were often unable to successfully conclude an adoption procedure as home governments had not supplied them with papers. ${ }^{20}$ It was to solve this type of problem that the ISS - which had a consulting role in the $\mathrm{UN}$ - was led to intervene in adoption cases. It tried hard to meet the requests for information which had been brought before its national offices by collaborating with the social services of the countries of origin. The French branch of the ISS, the Service Social d'Aide aux Emigrants (SSAE) played a large role in the adoptions of German children by American couples garrisoned in France. In the 1950s, a German mother who abandoned her child at the Youth Office (the German equivalent of welfare services) knew it was likely to be adopted by Americans living in Europe. For those in France, the Youth Office asked the SSAE to enquire on candidates. After a child was placed, the SSAE was once again called upon to establish a report on his integration into his new American family. The intervention of the SSAE was thus strictly social, legal questions were attended to between the German and American governments. ${ }^{21}$ It is understood then that in no circumstance did the ISS and its national branches play the role of go-between in the placement of children, rather it had a role of support and help in in facilitating the legality and transparency of procedures. $^{22}$ In most cases, the governments themselves, European and American especially, appealed to the ISS. ${ }^{23}$ In doing so, the administrators and social worked of the ISS regularly pointed out the inadequacy of national laws and international rules in addition to the poor application of existing legislation.

18 FAM, Administrative Conventions Series (from now on CAAC) AC Volume 1, Box No. 3, Letter from the Justice Minister to the Foreign Affairs Minister, 26 August 1952.

19 Josephine Baker adopted twelve children of all colours, origins, religions and nationalities in order to raise them according to her ideal of universal brotherhood. See Yves Denéchère, note 2, p.56-63.

20 Yves Denéchère, La migration singulière des adoptés dans l'espace euro-américain depuis 1945, AMNIS, 2013, URL : http://amnis.revues.org/1980.

21 Camille Olivier, Adopter un enfant, Paris 1965, p.132-133.

22 Karen A. Balcom, The Traffic in Babies. Cross-border Adoption and the Baby-selling between the United States and Canada 1930-1972, Toronto 2011, p.161-162.

23 Camille Olivier, note 21, p.130-131. 
In substance, the ISS position on adoption was clear: "finding adoptive parents for children who particularly needed them and who did not have the possibility to be adopted in their own countries, rather than supplying children to parents who wished to adopt a child from a another country." ${ }^{24}$ This was the philosophy of international adoption expressed from the 1920s onward. In concrete terms, the ISS realistically and constructively intervened in intercountry adoptions in order to introduce the best guarantees possible, as much from a legal as a social point of view. Throughout 1956, ISS offices dealt with 3,500 placements of children in foreign families concerning fifty-four countries. ${ }^{25}$ The large number of international adoptions can largely be explained by the enactment of an American law, the Refugee Relief Act of 1953, which provided for the admission of four thousand children to the United States before the end of $1956{ }^{26}$

In the 1960s, a European couple who went to Greece with thoughts of adopting could do so in a month (statutory time limit in Greece), be entrusted with a child, and obtain a ruling of adoption. This very short period, and its corollary reflection on on both sides, was sometimes detrimental to the child's best interest: a case was reported of a French woman adopting a child, and then returning to France without him after changing her mind . . ${ }^{27}$ Adoptions of Italian children took place in France. The head of Health and Social Affairs of the Maine-et-Loire highlighted the fact that an Italian charity from Turin organised the placement of some children in that département. But according to Italian authorities, too many French couples easily crossed the border with an Italian child handed over to them by an institution for abandoned children. Through its consulates in France, Italy then asked the ISS and the SSAE to assure that adoptions of Italian children be carried out lawfully. ${ }^{28}$

The great evolution of the 1960s, however, was that from that point onward a movement of adoption developed from Asia toward Europe. Arriving from Lebanon, India, South Korea, and Vietnam, hundreds of children arrived each year in Europe to be adopted in France, Belgium, Germany, the Netherlands and Norway...very few in the United Kingdom, where international adoption was and has remained marginal. As the countries of origin became more and more numerous the countries of Western Europe all more or less became host countries; once a country of origin, Italy became a host country. This evolution of the migratory movements of intercountry

${ }^{24}$ FAM, CAAC, AC 1, No. 3, "Adoption entre pays: rapport d'un groupe d'experts européens, Genève 21-25 janvier 1957), United Nations, 1958, TAA/EG Rep.3, p.3-4.

Ibid, p. 4

Christopher Bagley (ed.), note 15, p.148-149.

Camille Olivier, note 21, p.135-136

28 Archives of the Département Maine-et-Loire, $303 \mathrm{~W}$ 82, annual activity report of the Department of Social Services -- DASS (1968-1969); Jean Foyer Collections, 818 J, Report from the DASS of Maine-et-Loire "les adoptions en Maine-et-Loire" for the years 1967-1969. 
adoption pushed the Council of Europe to propose a convention.

\section{B - The Contribution of the Council of Europe}

\section{$\underline{\text { I-The necessity for inter-institutional dialogue }}$}

In 1952, the World Health Organisation (WHO), organised a meeting on adoption in New York with the aim of drawing up universal statutes. Obviously, governments were very reticent to accept guidelines on a practice over which they had exclusive jurisdiction. ${ }^{29}$ Yet, in transnational adoptions, a minimum amount of harmonisation is necessary to preserve the rights of the children as well as those of the biological and adoptive parents. On the international level, the first reflections of the ISS on this new phenomenon were shared by the UN services concerned and the brand-new Council of Europe (COE), which gathered the main host countries of international adoption in the 1950s and 1960s (Belgium, Denmark, France, Norway, the Netherlands, and Sweden) and also countries of origin (Italy and Greece). ${ }^{30}$ In the 1950 s then, the new European institution started to look into these "intercountry adoptions." Indeed, at the time there existed no regulatory guidelines, no international text which organised and controlled this particular type of migration of thousands of European children, intra-European migration coupled with intercontinental migration. The Committee of Ministers of the Council of Europe, in a special message on 20 May 1954, proclaimed its intention "to study the means of unifying and harmonising the legislation of member states" and wished to receive the suggestions of the consulting Assembly. In this way, the Social Committee and the Legal Commission initiated work to reflect upon, define and establish statistics on the migratory phenomenon of transnational adoptions. ${ }^{31}$

In August 1956 in Germany, the ISS brought its personnel together and drew up a certain number of principles. Then, in accordance with the United Nations' European Office of Technical Assistance, a group of European experts met in Geneva from 21-25 January 1957 to decide what action to take. The fundamental principle which inspired the group's work was that "adoption, whatever its form, must have only one objective: the good of the child." This was consistent with

29 Rachel Gayman, Le problème de l'adoption, Cahiers français d'Informations. Quatre études sur la jeunesse socialement inadaptée, No. 283, (1955), p.20-26.

30 At its creation in May 1949, the COE counted ten member states: Belgium, Denmark, France, Ireland, Italy, Luxembourg, the Netherlands, Norway, Sweden, and the United Kingdom. Joining later were Greece (1949), Turkey (1949), the Federal Republic of Germany (1950), Iceland (1950), Austria (1956), Cyprus (1961), Switzerland (1963), Malta (1965), and others followed after our period of study. For the history of the institution, see particularly Birte Wassenberg, History of the Council of Europe, Strasbourg 2013.

31 CAAC, AC 1, Box Number Three contains documents on transnational adoption issued by the Council of Europe (1957-1968), particularly several reports on the different steps of the consideration of the transnational adoption question by the COE. 
the UN position "which considered adoption to be one of the important principles in its policy of the protection of childhood." The beginning assessment was clear and well defined the situation of international adoption at the time: "in many countries, the verification of the delivery of passports to emigrating children [...] is careless [...] and encourages the placements of children from one country to another without the necessary preparation and protections." ${ }^{32}$

During the work in Geneva, two directions were explored: first "to increase possibilities for adoption within each country, which would reduce the need for adoption between countries," then to establish "conditions in which intercountry adoption could be carried out [...] with the most serious guarantees in cases where it is judged to be necessary and desirable, given that one would expect cases of this type to continue to come up." ${ }^{33}$ The first direction entailed a reflection upon adoption in general in each country, which was not always well accepted by governments; the second was to find a modicum of legal harmonisation among governments in order to establish rational bases to confront the unbridled development of a growing phenomenon. The work of these experts resulted in the drawing up of twelve principles, short and very expressive. They stated that the good of the child was the principal element upon which all aspects of adoption should be based. $^{34}$

In November 1959, at the UN General Assembly, the international community unanimously adopted the Declaration of the Rights of the Child. Based on the previous great declarations of human rights, the text lists ten great principles so that each child may have "a happy childhood and enjoy for his own good and for the good of society the rights and freedoms herein set forth." Here was a veritable recognition of children's rights, to that point the legal status of children had especially been specified. Adoption was not mentioned, but Principle Six stipulated that the child "shall, wherever possible, grow up in the care and under the responsibility of his parents, and, in any case, in an atmosphere of affection and of moral and material security; a child of tender years shall not, save in exceptional circumstances, be separated from his mother. Society and public authorities shall have the duty to extend particular care to children without a family and to those without adequate means of support." 35

At the end of the 1950s and the beginning of the 1960s, the number of international adoptions known to the ISS soared: 6,316 cases in 1961 - of course other cases existed, not known

\footnotetext{
CAAC, AC1, No. 3, "Adoption entre pays : rapport... ", p.44.

33 Ibid, p.2 and 4-5.

Ibid, annex 3, p.55-58.

35 UN General Assembly, 20 November 1959; Françoise Dekeuwer-Défossez, Les droits de l'enfant, Paris 2006.
} 
to the ISS. ${ }^{36}$ The group of experts meeting in Geneva in January 1957 had recommended the meeting of an international seminar, whose work could make proposals which the UN would address to governments and the Council of Europe.

\section{$\underline{\text { II - Drawing up principles }}$}

The Social Committee of the Council of Europe, at its Eighth Session (30 November - 4 December 1959), after having heard a talk by a UN representative on the problems linked to transnational adoption, decided to contribute to finding solutions. The Council of Europe looked to write a regional convention with model regulations whose principles would apply to member states. The first measure for the Council of Europe was to send an observer to the seminar the group of experts had wished for in 1957, held in Leysin, Switzerland from 22 - 31 May $1960 .^{37}$

The seminar was organised by the United Nations Technical Assistance Administration as a part of the special programme of social service for Europe, and in collaboration with the Swiss government, the ISS and the IUCW. The seminar was reserved for European participants who, through their experience, could bring a positive contribution to the studies and promote the spread of new ideas in their countries. So that meant social workers dealing with adoption, legal experts, and civil servants. The Council of Europe, the Hague Conference on Private International Law, and the National Catholic Welfare Conference sent observers. ${ }^{38}$

The work done in Leysin was based on "two axioms": "1 - Adoption is the best replacement for a biological family[...] 2 - The aim is above all to promote the well-being of the child." The different work groups in Leysin took up the twelve principles formulated by the group of experts in Geneva in 1957 and would propose practically the same text to create a fundamental charter to diffuse and apply. The six first principles related to adoption in general and the last six were proper to intercountry adoption. Principle One focused on adoption's goal: "Adoption is the best replacement for the care given to a child by his parents or his immediate family, on the condition that this adoption be principally founded on the well-being of the child." All possibilities for adoption in the home country must be studied before a foreign placement is considered, "given that it is risky to transplant a child outside of his cultural environment" (Principle Two). According to Principle Three, the adoption of children placed in an institution should be carried out as early as

36 CAAC, AC 1, No.3, "L'adoption des enfants entre pays", report of the Division des Questions sociales, CE/Soc (60) 24, 3 November 1960, p.2

37 CAAC AC 1, No. 3, "Rapport de mission rédigé par l'observateur du Conseil de l'Europe au Cycle d'études européen de Leysin sur l'adoption entre pays ", CE/Soc (60) 12, 25 July 1960, p.1-2.

38 Ibid, p.3. 
possible. In each country, efforts should be made to find families for physically or mentally disabled children (Principle Four). The fifth principle stated that every parent should be in a position to evaluate the consequences of adoption for his child before consenting to it. The same necessity applied to the adopted child if he was of an age to understand and to make a choice (Principle Six). ${ }^{39}$

Out of the last six principles came the statement of the guarantees which should accompany each international adoption. An investigation must absolutely be done into the home of the adopting parents as well as into the child (Principle Seven). This investigation must determine the choice of a child's adoptive family by the child protection agency, particularly by taking religion into account (Principle Eight). The necessity of a placement lasting at least six months in the family before the adoption is clearly confirmed (Principle Nine), which aimed to eradicate the practice of adoption by mandate, in other words an adoption carried out before the adopting parent had even seen the adoptee. The fact of insisting on the necessity of possessing all documents in due form in order to carry out the adoption (Principle Ten) proves that this was a practice which was not always respected. Principle Eleven considered the period between the arrival of a child in a foreign country and his official adoption as one of the most critical regarding the protection of the child. Finally, the best interest of the child also demanded that his adoption be acknowledged in his country of origin (Principle Twelve), which was hardly the case in 1960 as national legislation on the subject varied greatly. $^{40}$

As far as the manner in which these principles were applied is concerned, the Leysin meeting recommended the "social casework" method in the different phases of adoption, in reaction to the all too frequent intervention of unqualified people: "their ignorance of social, psychological, and legal elements can have tragic consequences for the children, their biological parents, and their adoptive parents." It was then indicated that a "service of trained casework is vital to inform candidates for adoption and the biological parents of the legal consequences of adoption and to enlighten them about its psychological consequences." The list of recommendations was long. The experts seemed to have foreseen every instance, every difficulty which came up or which could come up in the legal or social domain or the protection of children. The Leysin seminar also produced a draft of a convention, in six titles and sixteen articles, "intended to inspire the authors of a European tool," whose goal would be to "protect the interest of the adopted child, whose well-

39 Marie-Pierre Marmier, L'adoption, Paris 1972, p.100-102.

40 Camille Olivier, note 21, p.137-142 ; Marie-Pierre Marmier, note 39, p.103-104. 
being is absolutely predominant." 41

\section{$\underline{\text { III -Toward a European Adoption Convention }}$}

As seen above, the main principles of intercountry adoption were unanimously defined in 1957 and 1960. Neither formalised nor inscribed in international law, they were not restrictive for governments, international organisations, or the national associations which handled adoption. The role of the different organs of the Council of Europe were then of paramount importance in moving toward an international text.

In 1960, the Social Committee raised the following point on intercountry adoption: "Such is the problem at hand: that of general inadequacy." It was thus urgent to "go back over the logic de transnational adoption of children in trying to improve it at its different stages." The convention draft of sixteen points established by the experts in Leysin seemed to be an interesting base for writing a convention whose object was to "protect the interest of the adopted child, whose wellbeing is absolutely predominant." ${ }^{42}$ The Legal Commission insisted that legislation of member states of the Council of Europe be harmonised "in compliance with modern concepts." Legal conflicts brought about by intercountry adoption were indeed very numerous. The main question lay with determining the competent local authority, and so the law to apply, to authorise the adoption and to manage its impacts: was it the law of the adopter's country or that of the adoptee's? ${ }^{43}$

Drawing on this report, the Social Committee decried the lack of precise statistics but considered that from the evidence, "adoptions among member states of the Council of Europe were few compared to the adoptions carried out between European countries and other countries." It affirmed that the problems relative to intercountry adoption were to be put in the wider framework of adoption in general. It noted the very great disparities in national legislation and the impossibility of moving towards uniform regulations or a restrictive convention. So it proposed establishing "a convention only containing a minimum of essential principles" accompanied by recommendations that each member committed to implementing in its legislation. ${ }^{44}$ This option

41 CAAC AC 1, No. 3, "Rapport de mission...", p.13

42 CAAC, AC 1, No. 3, "L'adoption des enfants entre pays", report of the Division des Questions sociales, CE/Soc (60) 24, 3 November 1960, p.2.

43 CAAC AC 1, No. 3, " Rapport sur le droit de l'adoption", Legal Commission of the COE, AS/Jur XV (12) 5, 5 April 1961.F

44 CAAC AC 1, No. 3, "Conclusions du sous-comité d'experts pour l'adoption des enfants entre pays", Council of Europe, CE/Soc (61) 3, 17 April 1961, p.2. 
completely suited all the member states, particularly France who did not want a text which was too legally restrictive in order to preserve "pluralism of forms when it has historically existed and meets a pluralism of needs." Reference was of course being made here to the specificity of the two forms of French adoption, with or without a break with the biological parents. ${ }^{45}$

In Recommendation 292 (1961), the consulting Assembly of the Council of Europe, "Considering that adoption exists as a legal institution in all member countries of the Council of Europe, but that national legislation on the subject differs both as to the form and as to the substance of adoption," invited the Committee of Ministers, "should appoint a committee of governmental experts [...] to draft a convention which would contain a minimum of essential principles in regard to adoption." ${ }^{46}$ This is what was done starting in 1962: a sub-committee on adoption met regularly and worked on writing a convention draft. It endeavoured to deal with adoption in general whilst always keeping in mind the problems of international adoption. ${ }^{47}$

The Hague Conference on Private International Law, which had sent -- it too -- an observer to Leysin, set to work a special commission which settled upon a draft for a "Convention on International Adoption" in March 1963. It was debated and led to a final document on 7 October 1964 aiming to resolve conflicts of jurisdiction and assure the recognition of granted adoption decisions. The twenty-four articles of the convention "concerning the jurisdiction of authorities, the applicable law and the recognition of decisions on the subject of adoption" concluded 15 November 1965 particularly dealing with the authorities competent to grant adoptions (Article Three), the conditions of social enquiries (Articles Six and Seven), questions of nationality (Article Ten) or adoption bans, for example the age conditions between adopter and adoptee (Article Thirteen). The main principle is that in legal conflicts, the judge applies his own law, meaning most often the law of the host country, except for what concerns the consent of the child's birth parents. ${ }^{48}$

After several years of reflection and writing, the European Convention on the Adoption of Children was opened to the signature of Council of Europe members on 24 April 1967. Containing twenty-eight articles organised in four parts, it was the most complete text on adoption to date. ${ }^{49}$ Its impact was to insure that child protection measures were applied equally to the adoptions of foreign

45 Letter from the French Minister of Public Health and Population to the FAM, AG 4-5531, 4 July 1961.

46 Consultative Assembly of the Council of Europe, Recommendation 292 (1961) on the law of adoption, 26 September 1961.

47 CAAC AC 1, No 3, "Réunion d'un groupe de travail du sous-comité pour l'adoption", Note of the Secretary General of the Committe of Ministers, CM (62) 22, 26 January 1962.

48 Hans van Loon, Genèse et historique de la Convention du 29 mai 1993, in L'adoption internationale, colloque Louis Chatin, Paris 1994, ronéotypé, p.9-17.

49 Part I: Undertakings and field of application (Articles 1-3); Part II: Essential provisions (Articles 4 -16); Part III: Supplementary provisions; Part IV: Final clauses (Articles 21- 28). 
children, whether European or from other countries of origin. To do this, it took the main principles drawn up earlier but cut them back to a minimum so that they would be acceptable for all states which had to integrate them into their own legislation. It also provided an additional list of measures which states were free to implement if they so chose. The three main principles chosen were the following: the adoption must be ordered by an administrative or legal authority, the decision to offer a child up for adoption must be freely accepted by the parents, and the adoption must insure the child's well-being. Signed by eleven countries and ratified by six of them, it went into effect on 26 April 1968; in total, eighteen states ratified the convention and three signed it. ${ }^{50}$ The convention then could not settle all cases of international adoption, particularly between the countries of Western and Eastern Europe. Certain countries would then contract bilateral conventions, such as the Franco-Polish Convention of 5 April 1967 which stipulated that the conditions and effects of adoption are those of the adoptee's law and that the forms of adoption are subject to the national law of the adopter, or the Franco-Yugoslav Convention of 18 May 1971 which stipulated that the authorities of both countries have the jurisdiction to grant an adoption. ${ }^{51}$

\section{Conclusion}

The efforts of the Council of Europe to regulate a complex transnational social reality like international adoption on the European level illustrates how the institution tried to tackle a problem which could hardly find a way forward in the bilateral relationships between governments. On the contrary, the Council of Europe fit within a group of interactions with other international organisations like ISS or the Hague Conference on Private International Law, and made possible the proposition of a general approach to a very unique type of migration.

The COE arrived at the conclusion that a convention was necessary, laying out essential principles as per the respect of the rights of children (in reference to the 1959 UN Declaration of the Rights of the Child). Within the Council of Europe, a long negotiation effort ended in the writing of the European Convention on the Adoption of Children (1967). International adoption was still developing in the 1970s, and this minimalist text quickly became insufficient. Many Council of Europe member states had indeed revised their legislation according to social and legal changes, and certain provisions of the Convention became obsolete.

As early as 1977, at the first European conference on family law, the necessary update of the

50 European Convention on the Adoption of Children, Council of Europe, (CETS No. 058), 1967.

51 Hélène Gaudemet-Tallon, Le droit français de l'adoption internationale, Revue Internationale de Droit Comparé, n42-2 (1990) p.567-597. Caroline Mécary, L’adoption, Paris 2006, p.104-105. 
convention was brought up. ${ }^{52}$ For their part, Third World nations, countries of origin for international adoption, considered that the convention was written to benefit the European host nations which had put it together. ${ }^{53}$ As if in reaction, in La Paz in 1984 Latin American countries drew up a convention on legal conflicts in adoption. It gave jurisdiction to judges of a child's home country applying the laws of their country, except for the criteria aimed at the adopters. ${ }^{54}$

In 1988, the Council of Europe's Committee of Experts on Family Law put certain questions on adoption on its working agenda, but a new text was written on an international level as a part of the Hague Conference on Private International Law. This work led to the Hague Convention on Protection of Children and Co-operation in Respect of Intercountry Adoption in May $1993 .{ }^{55}$ This convention has generally presided over international adoption in the world since it went into effect (1 May 1995). On a European level, Recommendation 1443 (2000) launched an effort to review and adapt the 1967 convention in order to ensure compliance with the convention of the Hague. This process concluded in $2008 .^{56}$

52 Hans van Loon, note 48, p.9-17

33 Maev O'Collins, The influence of Western adoption laws on customary adoption in the Third World, in Philip Bean (ed), Adoption. Essays in Social Policy, Law and Sociology, London 1984, p. 288-304.

54 Francisco J. Pilotti, Intercountry Adoption : A view from Latin America, Child Welfare, n ${ }^{\circ}$ LXIV-1 (1985), p.25-35.

55 Hans van Loon, note 48, p.9-17

56 European Convention on the Adoption of Children (Revised), Council of Europe, 2008, (CETS No. 202). 